JKM (Jurnal Kebidanan Malahayati),Vol 7,No.2.April 2021,

ISSN (Print) 2476-8944 ISSN (Online) 2579-762X, Hal 143-148

\title{
ASUPAN SARI KACANG HIJAU (VIGNA RADIATA) PADA IBU NIFAS MEMPENGARUHI BERAT BADAN BAYI
}

\author{
Amelia Donsu ${ }^{1 *}$, Fredrika N Losu², Hawa Marasabessy³ \\ 1,2,3Jurusan Kebidanan Politeknik Kesehatan Kementerian Kesehatan Manado, \\ *Korespondensi ameliyaks.donsu@gmail.com
}

\section{ABSTRAK MATERNAL INTAKE OF GREEN BEAN (VIGNA RADIATA) JUICE AFFECTS BODY WEIGHT IN INFANTS}

Background: breast milk is an emulsion of fat in a solution of protein, lactose and organic salts secreted by both glands of the breast, as the main food for babies. The reality of exclusive breastfeeding coverage in Indonesia is only 35\% and in the Kombos Community Health Center in January 2019 there were 30\% (15) mothers with substandard breast milk production. One way to facilitate the production of breast milk is to consume green bean extract (vigna radiata). Green beans (vigna radiata) is a plant that can grow almost everywhere in Indonesia. Green bean extract contains vitamin B1 (thiamin) which functions to convert carbohydrates into energy, strengthen the nervous system and is responsible for the production of breast milk.

Purpose: The purpose of this study is to determine the effect of the intake of green bean extract (vignaradiata) Juice Affects Body Weight in infants in Puskesmas Kombos, District Singkil, Manado.

Method: The method used in this study was the experiment of all the quasy experiments with the One Group Pretest-Posttest Design research design, Accidental Sampling Type, namely 30 people with the treatment given in the form of giving green bean extract (vignaradiata) postpartum mothers to breast milk adequacy in infants at the Kombos Health Center Singkil District, Manado City. The instrument used in this study was Observation Sheet, Chechlist Sheet, Informed Consent Sheet. Data analysis used was univariate analysis in the form of frequency distribution and presentation, while bivariate analysis used the t test.

Results: The results of the study and discussion showed that there were differences in the mean (mean) before consuming green bean extract which was 9.80 and after consuming green bean juice which was 12.40. The results of the analysis using the Wilcoxon test get $p$ value $=0.002$ which means there is an influence of the intake of green bean extract on the adequacy of breast milk in infants.

Conclusion that there is an Affects Body Weight in infants on the provision of Green Beans juice drinks in the Kombos Community Health Center, Singkil District, Manado City.

Suggestion For postpartum mothers, besides consuming Green Beans juice drinks, it also consumes foods that contain nutrients to increase milk production to meet the needs of the baby.

\section{Keywords : Intake of Green Bean,Post Partum,Body Weight}

\begin{abstract}
ABSTRAK
Latar Belakang: Air Susu Ibu (ASI) adalah suatu emulsi lemak dalam larutan protein, laktosa dan garam-garam organik yang disekresi oleh kedua belah kelenjar payudara ibu, sebagai makanan utama bagi bayi. Kenyataan cakupan ASI Ekslusif di Indonesia hanya 35\% dan di Puskesmas Kombos bulan Januari 2019 terdapat 30\% (15) ibu dengan produksi ASI yang kurang lancar. Salah satu cara untuk memperlancar produksi air susu ibu yaitu dengan mengkonsumsi sari kacang hijau (vigna radiata). Kacang hijau (vigna radiata) merupakan tanaman yang dapat tumbuh hampir di semua tempat di Indonesia. Sari kacang hijau mengandung vitamin B1 (thiamin) yang berfungsi untuk mengubah karbohidrat menjadi energi, memperkuat sistem saraf dan bertanggung jawab untuk produksi Air Susu lbu.

Tujuan: Tujuan penelitian ini yaitu untuk mengetahui pengaruh konsumsi sari kacang hijau (vigna radiata) pada ibu menyusui terhadap berat badan bayi di Puskesmas Kombos Kecamatan Singkil Kota Manado.

Metode: Metode yang digunakan dalam penelitian ini adalah eksperimen semu atau quasy experiment dengan rancangan penelitian One Group Pretest-Posttest Design, Jenis Aksidental Sampling yaitu 30 orang dengan perlakuan yang diberikan berupa pemberian sari kacang hijau (vigna radiata) ibu nifas terhadap berat badan bayi di Puskesmas Kombos Kecamatan Singkil Kota Manado. Instrument yang digunakan dalam penelitian ini Lembar Observasi, Lembar Chechlist, Lembar Informed Consent Analisa data yang digunakan yaitu analisa univariat berupa distribusi frekuensi dan presentasi, sedangkan analisa bivariate menggunakan uji $t$ test.
\end{abstract}


Hasil penelitian: Hasil penelitian dan pembahasan menunjukkan bahwa ada perbedaan rata-rata (mean) sebelum mengkonsumsi sari kacang hijau yaitu 9,80 dan sesudah mengkomsumsi sari kacang hijau yaitu 12,40. Hasil analisis menggunakkan uji $t$ test mendapatkan nilai $p$ value $=0,002$ yang berarti ada pengaruh asupan sari kacang hijau terhadap kecukupan Air Susu Ibu pada bayi.

Kesimpulan bahwa terdapat pengaruh kecukupan ASI terhadap pemberian minuman Sari Kacang Hijau di Wilayah Kerja Puskesmas Kombos Kecamatan Singkil Kota Manado.

Saran Bagi ibu nifas selain mengkonsumsi minuman Sari Kacang Hijau, juga mengkomsumsi makanan yang mengandung zat gizi untuk meningkatkan produksi ASI agar mencukupi kebutuhan bayi.

\section{Kata Kunci: Asupan Sari Kacang Hijau ,Ibu Nifas,Berat Badan Bayi}

\section{PENDAHULUAN}

Air Susu Ibu (ASI) adalah suatu emulsi lemak dalam larutan protein, laktosa dan garamgaram organik yang disekresi oleh kedua belah kelenjar payudara ibu, sebagai makanan utama bagi bayi (Widaryanti, 2015).

Air Susu lbu eksklusif adalah pemberian Air Susu lbu selama 6 bulan tanpa pemberian minuman atau makanan apapun, termasuk air bening., vitamin dan obat (Maryunani, 2012). Proses menyusui akan membuat bayi mendapatkan asuhan gizi yang cukup dan limpahan kasih sayang yang berguna untuk perkembangannya, pencapaian perkembangan yang optimal juga dapat dilakukan dengan menyusui bayi secara penuh (Air Susu Ibu murni/ekslusif) selama 6 bulan dan dilanjutkan sampai berumur 2 tahun (Hidajati A, 2012).

Kacang hijau (vigna radiata) merupakan tanaman yang dapat tumbuh hampir di semua tempat di Indonesia. Sari kacang hijau mengandung vitamin B1 (thiamin) yang berfungsi untuk mengubah karbohidrat menjadi energi, memperkuat sistem saraf dan bertanggung jawab untuk produksi Air Susu Ibu, dimana thiamin akan merangsang kerja neurotransmitter yang akan meny ampaikan pesan ke hipofisis posterior untuk mensekresi hormon oksitosin sehingga hormon ini dapat memacu kontraksi otot polos mammae yang ada di dinding alveolus dan dinding saluran sehingga Air Susu Ibu dipompa keluar. Selain itu juga berguna untuk memaksimalkan sistem kerja saraf ssehingga mudah berkonsentrasi dan lebih bersemangat. Ibu yang mudah berkonsentrasi, bersemangat serta mood yang baik akan memicu kerja otak untuk memberikan informasi kepada impuls saraf agar menstimulasi hypothalamus dalam pembentukan hormon prolaktin dan oksitosin sehingga proses pembentukan Air Susu Ibu lancar (Reni,2014).

Hasil penelitian Wakhida (2011) di wilayah desa Bakalan Malang,menyatakan bahwa $75 \%$ ibu mengalami peningkatan produksi Air Susu Ibu, salah satu makanan tambahan yang mampu memperlancar Air Susu Ibu pada ibu menyusui yaitu kacang hijau. Hal ini sejalan dengan penelitian Kiky Widyastuti (2014) bahwa Konsumsi sari kacang hijau mempengaruhi produksi Air Susu Ibu (ASI) pada ibu menyusui di wilayah kerja Puskesmas Dinoyo Malang (Nugroho dkk, 2011).

World Health Organization (WHO) menyusui adalah proses pemberian Air Susu Ibu (ASI) kepada bayi sejak lahir sampai berusia 2 tahun, jika bayi diberikan Air Susu Ibu saja sampai usia 6 bulan tanpa menambahkan dan mengganti dengan makanan atau minuman lainnya merupakan proses menyusui eksklusif dan cakupan Air Susu lbu eksklusif di seluruh dunia hanya sekitar 36\% selama periode 2007-2014 (WHO, 2016).

Menurut Pusat Data dan Informasi Kementerian Kesehatan 2017, cakupan Air Susu Ibu eksklusif di Indonesia hanya 35\%, angka tersebut masih jauh di bawah rekomendasi WHO (World Health Organization ) sebesar $75 \%$. Data pemberian Air Susu Ibu eksklusif di Provinsi Sulawesi Utara tahun 2018 berjumlah 10.564 orang,dan untuk data ASI eksklusif di kota Manado tahun 2018 berjumlah 2047 orang (Dinkes Provinsi Sulawesi Utara, 2018).

Menurut survey awal yang dilakukan peneliti tanggal 13 Februari 2019 di Puskesmas Kombos Kecamatan Singkil Kota Manado diperoleh data jumlah persalinan normal tahun 2018 sebanyak 444 orang. Bulan Januari 2019 sebanyak 50 orang. Dan terdapat $15(30 \%)$ ibu dengan produksi ASI kurang.

Kendala yang dapat mempengaruhi pemberian Air Susu Ibu ekslusif salah satunya yaitu produksi Air Susu Ibu yang tidak lancar. Salah satu cara untuk memperlancar produksi Air Susu Ibu yaitu dengan mengkonsumsi sari kacang hijau, karena didalamnya terkandung berbagai komposisi gizi, diantaranya protein, zat besi dan vitamin B1. Protein berguna dalam membantu pembentukan sel-sel otot, mempercepat pemulihan dan meningkatkan daya tahan tubuh serta membantu kenyang lebih lama. Berdasarkan data di atas, maka peneliti tertarik untuk melakukan penelitian dengan judul "Asupan Sari Kacang Hijau (Vigna 
Radiata) Ibu Nifas Mempengaruhi Kecukupan ASI Pada Bayi".

\section{METODOLOGI PENELITIAN}

Jenis penelitian yang digunakan adalah penelitian eksperimen semu atau quasy experiment dengan rancangan penelitian One Group PretestPosttest Design. Perlakuan yang diberikan berupa pemberian sari kacang hijau (vigna radiata) ibu nifas terhadap kecukupan ASI pada bayi. Lokasi Penelitian Puskesmas Kombos Kecamatan Singkil Kota Manado. Sampel yang diambil sebanyak 15 orang, dengan teknik pengambilan sampel incidental sampling. Instrumen yang digunakan didalam penelitian ini adalah lembar Informed Consent, Lembar Checklist dan Lembar observasi. Analisis data menggunakan uji $T$ Test. Penelitian ini sudah melalui komisi etik dan sudah layak etik.

\section{HASIL DAN PEMBAHASAN}

Gambaran Umum Responden

Tabel 1.

Distribusi responden di Wilayah Kerja

Puskesmas Kombos Kota Manado

Berdasarkan Golongan Usia pada Tahun 2019

\begin{tabular}{ccc}
\hline \multicolumn{1}{c}{ Golongan Usia } & $\mathbf{f}$ & $\%$ \\
\hline$\leq 20$ tahun & 11 & 36,6 \\
$21-35$ tahun & 15 & 50 \\
$>35$ tahun & 4 & 13,4 \\
\hline Total & 30 & 100 \\
\hline
\end{tabular}

Tabel 1. Menunjukkan bahwa golongan usia responden di Wilayah Kerja Puskesmas Kombos yang paling banyak berusia antara 21-35 tahun yaitu sebanyak 15 responden (50\%) dan golongan usia yang paling sedikit terdapat pada golongan usia $>35$ tahun yaitu 2 responden $(13,4 \%)$.

Tabel 2. Menunjukkan bahwa golongan Pendidikan tertinggi pada golongan pendidikan SMU yaitu sebanyak 17 responden $(56,7 \%)$ dan golongan pendidikan yang paling terendah terdapat pada golongan pendidikan Perguruan Tinggi yaitu 1 responden $(6,7 \%)$.

Tabel 2.

Distribusi responden di Wilayah Kerja

Puskesmas Kombos Kota Manado

Berdasarkan Pendidikan pada Tahun 2019

\begin{tabular}{lcc}
\hline \multicolumn{1}{c}{ Pendidikan } & f & $\%$ \\
\hline SD & 4 & 13,3 \\
SMP & 7 & 23,3 \\
SMU & 17 & 56,6 \\
Perguruan Tinggi & 2 & 6,7 \\
\hline \multicolumn{1}{c}{ Total } & 15 & 100 \\
\hline
\end{tabular}

Tabel 3.

Distribusi responden di Wilayah Kerja

Puskesmas Kombos Kota Manado

Berdasarkan Paritas pada Tahun 2019

\begin{tabular}{|c|c|c|}
\hline Paritas & $f$ & $\%$ \\
\hline Primipara & 12 & 40 \\
\hline Multipara & 18 & 60 \\
\hline Total & 30 & 100 \\
\hline
\end{tabular}

Tabel 3. Menunjukkan bahwa golongan Paritas tertinggi pada golongan multipara18 responden $(60 \%)$ dan golongan paritas yang terendah terdapat pada golongan primipara yaitu 12 responden (40\%).

Tabel 4.

. Distribusi minum sari kacang hijau di Wilayah Kerja Puskesmas Kombos Tahun 2019

\begin{tabular}{lcc}
\hline $\begin{array}{c}\text { Minum Sari Kacang } \\
\text { Hijau }\end{array}$ & $\mathbf{f}$ & \% \\
\hline Teratur & 18 & 60 \\
Tidak Teratur & 12 & 40 \\
\hline \multicolumn{1}{c}{ Jumlah } & 30 & 100 \\
\hline
\end{tabular}

Tabel 5.

Rata-rata Berat Badan Bayi di Wilayah Kerja

Puskesmas Kombos Sebelum Diberikan

Minuman Sari Kacang Hijau Tahun 2019

\begin{tabular}{lccccc}
\hline \multicolumn{1}{c}{ Variabel } & N & Min & Max & Mean & SD \\
\hline $\begin{array}{l}\text { Hasil } \\
\begin{array}{l}\text { Pengukuran } \\
\text { Berat Badan }\end{array}\end{array}$ & & & & & \\
$\begin{array}{l}\text { Bayi sebelum di } \\
\text { berikan }\end{array}$ & 30 & 2500 & 3300 & 2950 & 180,5 \\
$\begin{array}{l}\text { Minuman Sari } \\
\text { Kacang Hijau }\end{array}$ & & & & & \\
\end{tabular}

Berdasarkan tabel 4 dapat diketahui bahwa distribusi mmnum sari kacang hijau di Wilayah Kerja Puskesmas Kombos dengan teratur sebagian besar terletak pada responden yang teratur minum sari kaacng hijau yaitu sebanyak 18 responden $(60 \%)$.

Berdasarkan tabel 5 dapat diketahui bahwa Ratarata Berat Badan Bayi di Wilayah Kerja Puskesmas Kombos Sebelum Diberikan Minuman Sari Kacang Hijau Tahun 2019 sebanyak 2950 gram 
Tabel 6.

Rata-rata Berat Badan Bayi di Wilayah Kerja Puskesmas Kombos Setelah Diberikan Minuman Sari Kacang Hijau Tahun 2019

\begin{tabular}{|c|c|c|c|c|c|}
\hline Variabel & $\mathrm{N}$ & Min & Max & Mean & SD \\
\hline $\begin{array}{l}\text { Hasil Pengukuran Berat Badan Bayi setelah di } \\
\text { berikan Minuman Sari Kacang Hijau }\end{array}$ & 30 & 2500 & 3400 & 3036,67 & 199,971 \\
\hline
\end{tabular}

\begin{tabular}{ccccc}
\hline Variabel & N & Mean & SD & $\rho$ value \\
\hline sebelum konsumsi Minuman Sari Kacang Hijau & 30 & 2950 & 180,5 & 0,0028 \\
\hline setelah konsumsi Minuman Sari Kacang Hijau & 30 & 3036,67 & 199,971 & \\
\hline
\end{tabular}

Pada tabel 6 Hasil analisis pada responden diperoleh Rata-rata Berat Badan Bayi di Wilayah Kerja Puskesmas Kombos Sebelum Diberikan Minuman Sari Kacang Hijau Tahun 2019 sebanyak 3036,67

Pada Tabel 7 dapat diketahui hasil uji t didapat $p$ value $0,000<0.028$ artinya $\mathrm{H}_{0}$ ditolak dan $\mathrm{Ha}$ diterima, yang berarti ada pengaruh konsumsi minuman Sari Kacang Hijau terhadap Berat Badan Bayi di Wilayah Kerja Puskesmas Kombos Tahun 2019

\section{PEMBAHASAN}

Analisis secara univariat didapatkan hasil penelitian rata rata berat badan bayi sebelum pemberian minuman Sari Kacang Hijau di Wilayah Kerja Puskesmas Kombos adalah 2980 gram, sedangkan setelah pemberian Minuman Sari Kacang Hijau, menunjukkan bahwaberat badan bayi adalah 3036,67 gram

Usia dan paritas berpengaruh juga terhadap produksi ASI. Ibu yang usianya muda lebih banyak produksi ASI dibandingkan dengan ibu yang sudah tua, dan menurut Biancuzzo (2003) bahwa ibu - ibu yang lebih muda atau usianya kurang dari 35 thn kebih banyak memproduksi ASI dari pada Ibu-lbu yang lebih tua, Ibu yang melahirkan anak kedua dan seterusnya Produksi ASI lebih Banyak dibandingkan dengan kelahiran anak yang pertama ( Enok Nurliawati, 2010 ). Pada Primipara denga usia 35 Thn keatas dimana reproduksi hormon relative berkurang, mengakibatkan proses laktasi menurun sedangkan pada usia ( 12 - 19 Tahun) harus dikaji pula secara teliti karna perkembangan fisik, Psikologis maupun sosialnya belum siap sehinga dapat menggangu keseimbangan psikologi dan dapat mempengaruhi dalam produksi ASI (Mursyida, 2013)
Tingkat pendidikan adalah proses dimana orang dihadapkan pada pengaruh lingkungan terpili dan terkontol, khususnya yang datan dari sekolah sehinga mereka dapat memperoleh atau mengalami perkembangan kemampuan sosial dan individu yang optimal. Manfaat menyusui hendaknya selalu di tekankan dari segi pendidikan keluarga terutama pada masa remaja karena pendidikan sangat mempengaruhi perilaku seseorang, dengan pendidikan seseorang mengetahui sesuatu hal, seseorang yang mempunyai pendidikan tinggi lebih cenderung mengetahui manfaaat ASI di bandingkan dengan yang berpendidikan rendah, sebab denganb pendidikan seseorang dapat lebih mengetahui sesuatu hal (Wahyu, 2014).Ibu nifas yang mengalami ketidaklancaran produksi ASI dianjurkan untuk mengonsumsi makan-makanan bergizi salah satunya sari kacang hijau karena sari kacang hijau bermanfaat untuk memperlancar keluarnya ASI Kandungan vitamin B1 yang terdapat pada sari kacang hijau mengubah karbohidrat menjadi energi karena ibu menyusui membutuhkan energi lebih besar dibandingkan saat hamil, jika kekurangan thiamin ibu akan mudah tersinggung, sulit konsentrasi dan kurang semangat.(Afifah,2020)

Hasil analisis secara bivariat untuk mengetahui pengaruh pemberian minuman Sari Kacang Hijau dengan menggunakan uji $t$ test menunjukkan nilai $p$ value $0,028<0,005$ artinya terdapat pengaruh yang signifikan antara pemberian minuman Sari Kacang Hijau terhadap Kecukupan ASI pada bayi di Wilayah Kerja Puskesmas Kombos.

Hasil penelitian ini sejalan dengan penelitian yang dilakukan oleh Dewi Triloka Wulandari, dkk (2015), di BPM Yuni Widaryanti, A.Md. Keb sumbermulyo Jogoroto Jombang, terhadap 7 orang responden dengan judul pengaruh pemberian sari 


\section{JKM (Jurnal Kebidanan Malahayati),Vol 7,No.2.April 2021, \\ ISSN (Print) 2476-8944 ISSN (Online) 2579-762X, Hal 143-148}

kacang hijau pada ibu nifas dengan kelancaran produksi ASI di dapatkan hasil penelitian menunjukkan bahwa $4(57,1 \%)$ ibu yang diberikan sari kacang hijau didapatkan ASInya keluar dengan lancar, sedangkan $3(42,9 \%)$ ibu yang diberikan sari kacang hijau didapatkan ASInya tidak bisa keluar dengan lancar. Selain itu penelitian ini juga didukung oleh penelitian yang dilakukan oleh Widyastuti, dkk (2014), di wilayah kerja puskesmas dinoyo malang. dengan hasil rata-rata pre test post test 1,60, kesimpulan bahwa konsumsi sari kacang hijau mempengaruhi produksi Air Susu Ibu (ASI) pada ibu menyusui. Perawatan payudara dapat meningkatkan pengeluaran ASI pada ibu post partum sehingga dapat digunakan sebagai SOP yang dapat diterapkan oleh tenaga kesehatan.(Fatmawati,2019)

ASI adalah suatu emulsi lemak dalam larutan protein, lactose dan garam-garam organic yang disekresi oleh kedua belah kelenjar payudara ibu, sebagai makanan utama bagi bayi. Faktorfaktor yang mempengaruhi komposisi air susu ibu adalah stadium laktasi, ras, keadaan nutrisi dan diit ibu. Air susu ibu menurut stadium laktasi adalah kolostrum, air susu transisi/peralihan dan air susu matur (Nugroho, 2011). Salah satu permasalahan yang terjadi yaitu banyak ibu nifas yang cenderung menolak menyusui bayinya sendiri dengan alasan air susunya hanya sedikit atau tidak keluar sama sekali, keadaan ini memberikan dampak negatif terhadap status kesehatan gizi pada anak.(Putri,2020)

Sari kacang hijau bukan merupakan obat dari bendungan ASI tetapi bisa membantu proses penyembuhan dari bendungan ASI. Jadi untuk penderita bendungan ASI atau ASInya tidak keluar lancar atau sedikit, tidak ingin periksa ke bidan atau dokter, dapat menggunakan sari kacang hijau sebagai alternatif dari pengobatan bendungan ASI dan ASI yang tidak keluar dengan lancar. Kandungan gizi dalam kacang hijau salah satunya tiamin yang berfungsi mengubah karbohidrat menjadi energy dan memperbaiki mood. Jika mood ibu menyusui baik maka dapat menghasilkan hormone oksitosin yang baik dalam melancarkan ASI. Selain harganya yang terjangkau, sari kacang hijau juga dapat dibuat sendiri atau dapat juga membeli sari kacang hijau yang sudah dalam kemasan, hal ini membuat para ibu-ibu yang merasa kesulitan menyusui anaknya karena ASI yang keluar tidak banyak semakin tertarik dan ingin mencobanya.

\section{SIMPULAN}

Hasil analisis secara bivariat untuk mengetahui pengaruh pemberian minuman Sari Kacang Hijau dengan menggunakan uji $t$ test enunjukkan nilai $p$ value $0,028<0,005$ artinya terdapat pengaruh yang signifikan antara pemberian minuman Sari Kacang Hijau terhadap Kecukupan ASI pada bayi di Wilayah Kerja Puskesmas Kombos.

\section{SARAN}

Bagi Tempat Penelitian dapat ditingkatkan lagi kegiatan penyuluhan pada ibu menyusui tentang manfaat minuman sari kacang hijau terhadap kecukupan ASI pada bayi guna menambah pengetahuan ibu menyusui. Bagi Masyarakat dapat diterapkan manfaat dari sari kacang hijau bagi kesehatan khususnya dalam meningkatkan produksi Air Susu Ibu.Bagi Responden mengkonsumsi minuman Sari Kacang Hijau, serta makanan yang mengandung zat gizi untuk meningkatkan produksi ASI agar mencukupi kebutuhan bayi. Bagi Peneliti hasil penelitian ini dapat meningkatkan pengetahuan dan wawasan sebagai acuan terhadap minuman yang dapat meningkatkan produksi ASI untuk kecukupan ASI pada bayi.

\section{DAFTAR PUSTAKA}

Afifah, N. (2020). Pengaruh Pemberian Sari Kacang Hijau (Vigna Radiata L) Terhadap Kelancaran ASI Pada Ibu Nifas Primipara hari ke 2 di Rumah Sakit Bantuan Lawang Kabupaten Malang (Doctoral dissertation, Poltekkes RS dr. Soepraoen).

Ambarwati, E, R,. Diah, W. (2010). Asuhan Kebidanan Nifas. Yogyakarta: Nuha Medika.

Arikunto, (2010). Prosedur Penelitian Suatu Pendekatan Praktek. Jakarta : Rineka Cipta.

Astutik. R.Y. (2014). Payudara dan Laktasi. Jakarta: Salemba Medika

Fatmawati, L., Syaiful, Y., \& Wulansari, N. A. (2019). PENGARUH PERAWATAN PAYUDARA TERHADAP PENGELUARAN ASI IBU POST PARTUM. Journals of Ners Community, 10(2), 169-184.

Fikawati. S. (2015). Gizi Ibu Dan Bayi. Jakarta : Rajawali Pers.

Hayati A.W. (2009). Buku Saku Gizi Bayi. Jakarta: egc

Hidajati A. (2012). Mengapa Seorang Ibu Harus Menyusui?. Jogjakarta:Flashbook.

Mardalena.I. (2017). Dasar-Dasar IImu Gizi Dalam Keperawatan. Yogyakarta : Pustaka Baru Press. 
Maryunani dan Anik. (2012). Inisiasi Menyusu Dini.ASI eksklusif dan Manajemen Laktasi. Jakarta: TIM

Notoadmojo.(2010). Metodologi Penelitian Kesehatan. Jakarta: Rineka Cipta

Nugroho dan Taufan. (2011). ASI Dan Tumor Payudara. Yogyakarta : Nuha Medika

Politeknik Kesehatan Manado, (2016). Pedoman Penulisan Skripsi. Kementerian Kesehatan R.I.

Purwono dan Hartono R.(2012). Kacang Hijau. Penebar Swadaya, Depok.

Putri, I. H., Kustiyati, S., \& Firrahmawati, L. (2020). SARI KACANG HIJAU MENINGKATKAN PRODUKSI ASI PADA IBU NIFAS.

Puskesmas Kombos. (2018) Buku Register Ruangan Bersalin Puskesmas Kombos Kecamatan Singkil Kota Manado.

Reni. (2014) Payudara dan Laktasi. Jakarta: Salemba Medika.

Rukmana R. (2014). ASI dan Panduan Ibu Menyusui. Yogyakarta: Nuha Medika.

Saleha dan Siti. (2009). Asuhan Kebidanan Pada Masa Nifas. Jakarta: Salemba Medika

Sulistyawati A. (2009). Asuhan Kebidanan Pada Ibu Nifas. Yogyakarta : C.V Andi offset.

Sunarsih dan Dewi.(2011). Asuhan Kebidanan Ibu Nifas. Jakarta: Salemba Medika.

Triyono A. (2010). Mempelajari pengaruh penambahan beberapa asam pada proses isolasi protein terhadap tepung protein isolate kacang hijau. Seminar Rekayasa dan proses. ISSN: 1411-4216.

Vivian N.L. (2013). Asuhan Kebidanan Ibu Nifas. Jakarta: Salemba Medika.

Wakhida. S.W. (2011). Pengaruh Konsumsi Kacang Hijau dengan Produksi ASI pada ibu Menyusui dengan Usia Bayi 0-6 Bulan. Malang: Akbid Wijaya Kusuma Malang.

Walyani , E.S dan Purwoastuti, E. (2015). Asuhan Kebidanan Masa Nifas \&Menyusui.Yogyakarta ; Pustaka Baru Press.

Widaryanti, Y (2015). Pengaruh pemberian sari kacang hijau pada ibu nifas dengan kelancaran produksi ASI di BPM. Sumbermulyo Jogoroto: Jombang. Jurnal Edu Health, Vol.5 No.2, September 2015

Widyastuti. K. (2014). Pengaruh Konsumsi Sari Kacang Hijau Terhadap Produksi Air Susu Ibu (Asi) Pada Ibu Menyusui Di Wilayah Kerja Puskesmas Dinoyo Malang. Malang: Fakultas IImu Kesehatan Universitas Muhammadiyah Malang.

Wiji, R.N.(2013).ASI dan pedoman ibu Menyusui. Yogyakarta: Nuha Medika

Wirakusumah.ES.(2010). Perencanaan Menu Anemia Gizi Besi. PT.Trubus Agriwidya. Jakarta.

Yulianti. (2011). Asuhan Kebidanan III (Nifas). Jakarta: TIM 